\title{
KLASIFIKASI BOTOL PLASTIK MENGGUNAKAN MULTICLASS SUPPORT VECTOR MACHINE
}

\author{
Arief Setyo Nugroho[1]; Rusydi Umar[2]; Abdul Fadlil[3]
}

Magister Teknik Informatika[1][2][3]

Universitas Ahmad Dahlan Yogyakarta

arief1908048023@webmail.uad.ac.id[1], rusydiumar@mti.uad.ac.id[2], abdulfadlil@mti.uad.ac.id[3]

\begin{tabular}{|c|c|}
\hline INFO ARTIKEL & INTISARI \\
\hline $\begin{array}{l}\text { Diterbitkan: } \\
1 \text { Desember } 2021 \\
\text { Kata Kunci : } \\
\text { Klasifikasi Citra, Multiclass, One vs } \\
\text { All, Radial Basis Function, Support } \\
\text { Vector Machine }\end{array}$ & $\begin{array}{l}\text { Sampah botol plastik perlu dipilah berdasarkan mereknya untuk } \\
\text { mengurangi polusi terutama botol plastik. Namun saat ini proses } \\
\text { pemilahan tersebut masih dilakukan secara manual. Jika pemilahan } \\
\text { dilakukan secara manual maka membutuhkan waktu yang lama, sehingga } \\
\text { perlu dibuat cara agar pemilahan dapat dilakukan dengan bantuan } \\
\text { teknologi. Teknologi pengolahan citra dapat mengklasifikasi beberapa } \\
\text { merek botol plastik. Klasfikasi citra botol plastik dilakukan dengan } \\
\text { menggunakan metode Multiclass Support Vector Machine (SVM) dengan } \\
\text { kernel Radial Basis Function (RBF). Klasifikasi botol plastik lebih dari } 1 \\
\text { kelas dapat menggunakan pendekatan One vs All. Kelas yang digunakan } \\
\text { berjumlah } 5 \text { kelas berdasarkan merek botol plastik yang berbeda seperti } \\
\text { Aqua, Coca-Cola, Fanta, Minute-Maid dan Sprite. Proses yang dilakukan } \\
\text { meliputi Pre-procesing Ekstraksi Ciri, Training dan Testing model. Pre- } \\
\text { processing dilakukan untuk menyiapkan citra sebelum proses Training dan } \\
\text { Testing. Ekstraksi ciri untuk mengetahui ciri dari masing-masing kelas. } \\
\text { Training dan Testing dilakukan dengan menggunakan } 500 \text { data citra yang } \\
\text { dibagi menjadi } 3 \text { kombinasi data citra latih dan data citra uji. Data citra } \\
\text { latih digunakan untuk Training model sedangkan data citra uji digunakan } \\
\text { untuk Testing model. Kombinasi data citra latih dan data citra uji yang } \\
\text { digunakan adalah } 75 \% \text { data citra latih dan } 25 \% \text { data citra uji, } 50 \% \text { data } \\
\text { citra latih dan data citra uji, serta } 25 \% \text { data citra latih dan } 75 \% \text { data citra } \\
\text { uji, sehingga menghasilkan } 3 \text { model yang berbeda. Hasil Testing klasifikasi } \\
\text { dari } 3 \text { kombinasi data cita latih dan data citra uji menghasilkan prosentase } \\
\text { keberhasilan berturut-turut sebesar } 56 \% \text {, } 70 \% \text {, dan } 84 \% \text {. }\end{array}$ \\
\hline
\end{tabular}

\section{PENDAHULUAN}

Sampah botol plastik yang semakin meningkat setiap harinya dapat mengakibatkan polusi pada lingkungan. Limbah dari botol plastik masih sulit terurai dan membutuhkan waktu yang lama. Sampah dari botol plastik sebenarnya dapat diolah kembali menjadi sebuah produk yang baru. Sebelum dilakukan proses daur ulang sampah botol plastik harus dipilah terlebih dahulu. Teknik pengolahan citra dapat dimanfaatkan sebagai metode yang dapat mengklasifikasi botol plastik sehingga mempermudah dalam memilah sampah botol plastik. Penelitian oleh (Wang dkk., 2019) yang melakukan klasifikasi botol plastik dengan mengelompokkan berdasarkan warna dan posisinya.

Teknik klasifikasi citra saat ini sudah banyak dikembangkan terutama untuk pengenalan objek yang mirip bentuk dan ukurannya. Salah satu problem yang saat ini dihadapi dalam pengembangan komputer visi adalah klasifikasi yang dapat memahami informasi pada citra sehingga dapat mengenali objek dengan baik (Putra dkk., 2016). Metode yang banyak digunakan pada proses klasifikasi citra adalah metode dari konsep ML (Machine Learning). ML merupakan sebuah model pembelajaran bagi komputer untuk dapat belajar secara mandiri berdasarkan data citra latih yang diberikan.

Machine Learning memiliki banyak metode yang dapat digunakan untuk klasifikasi citra seperti jaringan saraf tiruan, fuzzy logic, algoritma genetika, random forest (RF) dan support vector machine (SVM) (Neneng dkk., 2016). Metode yang sering digunakan dalam teknik klasifikasi citra yang lainnya adalah SVM karena dapat mengklasifikasi citra dengan akurasi yang cukup tinggi (Ibrahim dkk., 2019). Metode tersebut dirancang untuk dapat memisahkan kelas yang berbeda dengan membangun pemisah hyperplane yang lebih optimal(Thai dkk., 2012). Salah satu penerapan penggunaan SVM yaitu penelitian 
tentang Image Matching untuk mencocokkan logo (Umar dkk., 2020)(Riadi dkk., 2019)

Teknik klasifikasi juga telah banyak dikembangkan untuk mengklasifikasi data citra lebih dari dua dengan menggunakan Muticlass Cassifier (Banyal et al., 2016). Metode SVM dapat mengklasfisikasi lebih dari dua citra dengan menggunakan Multiclass SVM (Gitasari dkk., 2015). Salah satu contoh metode Multiclass SVM adalah One vs All yang membangun model klasifikasi dengan jumlah kelas yang di training pada data citra dari banyak kelas. Salah satu penerapan Multiclass SVM dengan menggunakan One vs All yaitu penelitian tentang klasfikasi penyakit diabetes retinopati dengan citra eksudat dan mikroaneurisma(aulia dkk., 2015). Metode tersebut melakukan training berdasarkan kelas yang diberikan dengan memanfaatkan data latih dan data uji.

Penelitian ini mengimplementasikan metode Multiclass SVM One vs All untuk mengklasifikasi citra sampah botol plastik berdasarkan label merek. Tujuan dari sistem ini diharapkan dapat digunakan dalam proses pemilahan sampah botol plastik.

\section{BAHAN DAN METODE}

Klasifikasi menggunakan SVM dibagi menjadi beberapa proses diantaranya adalah proses Pre-processing, Ekstraksi Ciri, Training dan Testing model. Data yang digunakan sebanyak 5 kelas yang dibagi berdasarkan merek botol plastik seperti Aqua, Coca-Cola, Fanta, Sprite dan Minute Maid Pulpy dengan ukuran sedang. Data citra dipilih karena dari masing-masing citra sebagian memiliki ciri yang hampir serupa. Jumlah data yang digunakan untuk masing-masing kelas memiliki jumlah 100 citra, sehingga total data citra yang digunakan sebanyak 500 citra.

Pre-Processing dilakukan untuk mempersiapkan data citra sebelum dilakukan proses Training dan Testing. Training data citra digunakan untuk mendapatkan model yang akan dimanfaatkan sebagai acuan dalam klasifikasi. Proses Testing dilakukan untuk menguji model dalam menentukan jenis botol berdasarkan kelas. Training dan Testing data citra dilakukan sebanyak 3 kali dengan menggunakan kombinasi data citra yang berbeda. Kombinasi dibagi menjadi data citra latih dan data citra uji. Kombinasi yang digunakan pada penelitian ini adalah kombinasi data 1, kombinasi data 2 dan kombinasi data 3 . Data citra latih digunakan sebagai model SVM sedangkan data citra uji digunakan sebagai penguji dari hasil model sehingga didapatkan nilai akurasi dari model.

SVM merupakan teknik klasifikasi data citra dengan proses latih dengan membadingkan suatu seleksi parameter dengan memanfaatkan persamaan hyperplane. Multiclass SVM dapat mengkategorikan data citra pengujian ke dalam beberapa label kelas berdasarkan model training seperti pada Gambar 1.

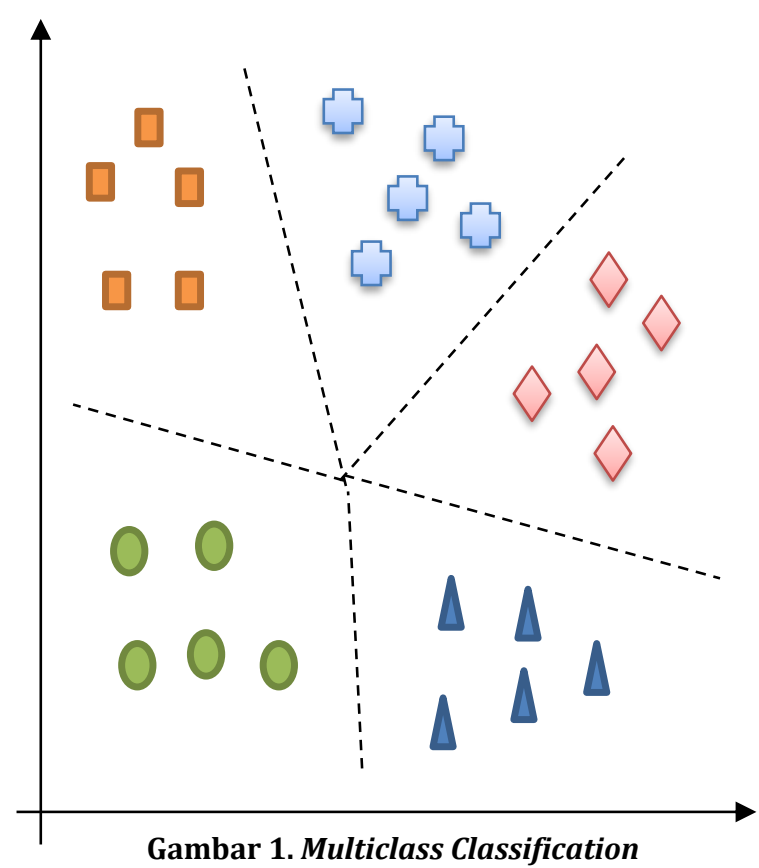

Metode Multiclass SVM yang digunakan pada penelitian ini adalah pendekatan One vs All. Metode ini akan mengklasifikasi data kelas dengan membangun sejumlah model SVM dalam biner (positif atau negatif). Metode ini akan melibatkan satu kelas sebagai sampel positif dan kelas yang lainnya adalah negatif. Hasil dari metode ini nantinya akan menentukan apakah data yang sedang diklasifikasi sesuai dengan kelas atau tidak. Rancangan sistem yang digunakan pada penelitian ini dapat dilihat pada Gambar 2 .

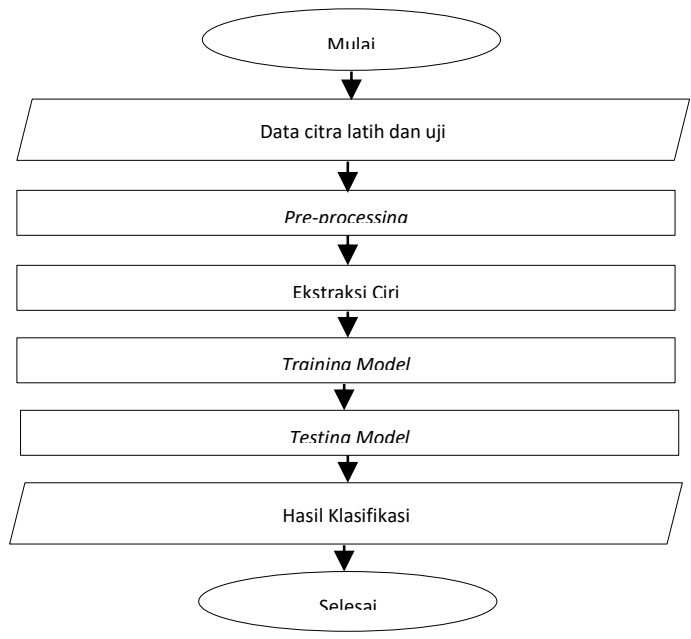

Gambar 2. Diagram Alir Perancangan Sistem 
Sistem dibuat dengan memasukkan data citra yang selanjutnya dilakukan Pre-processing. Setelah itu dilakukan proses ekstraksi ciri untuk mengenali ciri pada data citra. Data citra di Training untuk menghasilkan model. Model akan di Testing untuk menentukan klasifikasi kelas dari botol plastik. Proses dilakukan sebanyak 3 dengan kombinasi data yang berbeda. Keseluruan sistem ditulis menggunakan bahasa pemrograman python dengan software Anaconda.

\subsection{Pre-Processing}

Data citra botol plastik mengguakan 5 merek yang berbeda yaitu Aqua, Coca-Cola, Fanta, Sprite, dan Minute Maid botolnya dengan resolusi 2352 x 4160 pixel. Pengambilan data citra botol plastik dilakukan dengan menggunakan kamera smatphone Android Seperti yang telihat pada Gambar 3.
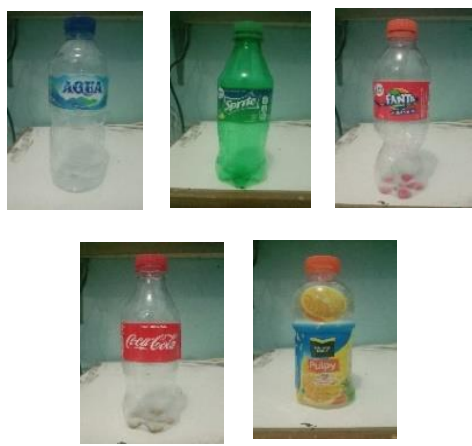

Gambar 3. Citra botol plastik

Proses tahapan pre-processing dilakukan proses pemisahan data citra yaitu data citra untuk Training dan data citra untuk Testing. Folder dibuat untuk 3 kombinasi data masing-masing. Program membaca folder yang telah dibuat dan akan melakukan split untuk memisahkan antara folder Training dan Testing berdasarkan kelas merek botol plastik. Seluruh data citra akan di Resize piksel menjadi 227 × 227 piksel. Tahapan proses pre-processing seperti pada Gambar 4.

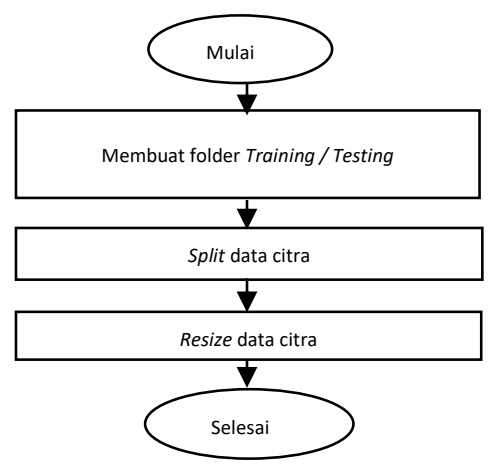

Gambar 4. Diagram Pre-Processing

\subsection{Ekstraksi Ciri}

Proses Ekstraksi ciri dilakukan dengan menggunakan metode GLCM untuk mendapatkan nilai ciri dari setiap kelas. Ciri GLCM yang diekstrak antara lain contrast, correlation, energy, dan homogenity.

\subsection{Training Model}

Proses training model dilakukan dengan menggunakan beberapa library tambahan. Training model dimulai dengan memanfaatkan Library ada pada pemrograman python yaitu library LabelBinarizer dari sklearn.preprocessing yang digunakan untuk mengkonversi nilai yang bertipe objek menjadi bentuk tipe data numerik. Selanjutnya dilakukan normalisasi data supaya data tidak terlalu besar menggunakan Fitur Scalling pada setiap data citra training dan data citra testing. Pada penelitian ini menerapkan algoritma SVM menggunakan kernel RBF (Radial Basis Function). Kernel ini merupakan SVM NonLinier yang dapat mengklasifikasi lebih dari dua kelas. Tujuannya adalah dapat menghasilkan akurasi dari model yang telah dibuat. Hasil akurasi ini digunakan untuk mengukur kualitas dari prediksi berdasarkan algoritma klasifikasi.

Proses Training dimulai dengan memasukkan data citra hasil Pre-processing dan Ekstraksi ciri. Pada tahapan Training, data citra akan diberikan label sesuai dengan kelasnya masing-masing. Proses pelabelan memanfaatkan pelabelan encoding dari library. Hasil akhir dari proses Training adalah model dari data citra yang telah dilatih. Tahapan prose Training terlihat pada Gambar 5.

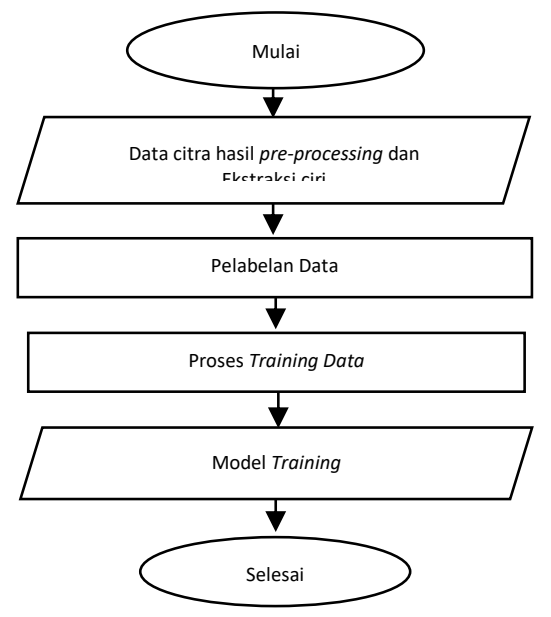

Gambar 5. Diagram Alir Training Data 


\subsection{Testing Data}

Data yang digunakan untuk Testing akan dilakukan proses Pre-processing, Ekstraksi Ciri dan proses Klasifikasi. Proses Testing data terlihat seperti pada diagram alir yang ditunjukkan pada Gambar 6.

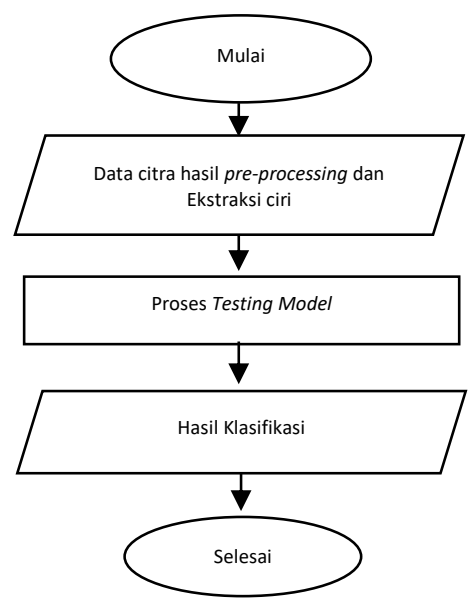

Gambar 6. Diagram alir Testing

Pada tahapan Testing digunakan untuk mengklasifikasi data citra sesuai kelas yang digunakan. Proses Testing diawali dengan memasukkan data citra yang telah dilakukan preprocessing dan ekstraksi ciri. Selanjutnya, dilakukan proses klasifikasi dengan memanggil model. Metode One vs All akan melakukan proses klasifikasi data citra sesuai dengan kelas.

Hasil dari klasifikasi akan dilakukan perhitungan akurasi dengan menggunakan Persamaan1. Tahapan keseluruhan sistem akan dilakukan sebanyak 3 kali sesuai dengan kombinasi data citra yang telah ditentukan.

Akurasi $(\%)=\frac{\text { Nilai Analisa }}{\text { Nilai Benar }} \times 100 \%$

\section{HASIL DAN PEMBAHASAN}

Hasil dari keseluruhan sistem ditampilkan secara berurutan dengan menampilkan data citra yang digunakan, pembagian data untuk Training dan Testing, serta pengujian dari model. Data yang digunakan pada penelitian ini seluruhnya dibagi seperti pada Tabel 1.

\section{Tabel 1. Database Citra}

\begin{tabular}{lll} 
No & Merek Botol & Total \\
\hline 1 & Aqua & 100 \\
\hline 2 & Coca-Cola & 100 \\
\hline 3 & Fanta & 100 \\
\hline 4 & Minute Maid & 100 \\
\hline 5 & Sprite & 100 \\
\hline Jumlah & & 500
\end{tabular}

Klasfikasi pada penelitian ini akan memisahkan menjadi 5 kelas berdasarkan merek botol plastik yang digunakan yaitu Aqua, CocaCola, Fanta, Minute Maid dan Sprite. Setiap kelas memiliki jumlah data citra yang sama yaitu 100 data citra, sehingga jumlah citra keseluruhan adalah 500 data citra. Pada setiap kelas akan diberikan sebuah kode untuk mempermudah dalam penentuan kelas. Kode mengimplementasikan nilai range klasifikasi dari setiap kelas. Kode yang digunakan terlihat seperti pada Tabel 2 .

Tabel 2. Kode Kelas

\begin{tabular}{cc}
\hline Merek Botol Plastik & Kode Kelas \\
\hline Aqua & 0 \\
\hline Coca-Cola & 1 \\
\hline Fanta & 2 \\
\hline Minute Maid & 3 \\
\hline Sprite & 4 \\
\hline
\end{tabular}

\subsection{Model Training SVM}

Model SVM dari Training yang sudah dilakukan akan menghasilkan 3 Model berbeda sesuai dengan kombinasi data citra. Persentase pada masing-masing data artinya data citra yang digunakan diambil berdasarkan persentase dari keseluruhan data yang digunakan. Pembagian data citra terihat seperti pada Tabel 3.

Tabel 3. Hasil akurasi model SVM

\begin{tabular}{ccc}
\hline $\begin{array}{c}\text { Jumlah data } \\
\text { Training }\end{array}$ & $\begin{array}{c}\text { Jumlah data } \\
\text { Testing }\end{array}$ & Nama Model \\
\hline $25 \%$ & $75 \%$ & Model 1 \\
\hline $50 \%$ & $50 \%$ & Model 2 \\
\hline $75 \%$ & $25 \%$ & Model 3 \\
\hline
\end{tabular}

Jumlah data citra yang digunakan untuk Testing terlihat berbeda jumlah. Hal tersebut dikarenakan jumlah data Training yang digunakan. Semakin banyak jumlah data citra yang digunakan dianggap semakin banyak variasi data citra yang di latih sehingga, untuk melihat akurasi maksimal saat jumlah data citra Training sedikit maka jumlah data citra Testing akan diperbanyak begitu pula untuk sebaliknya.

\subsection{Hasil Pengujian Kombinasi data 1 (Model 1)}

Pengujian pertama dihasilkan dari kombinasi $75 \%$ data latih dan $25 \%$ data uji. Pembagian data yang digunakan terlihat seperti pada Tabel 4 .

Tabel 4. Pembagian data kombinasi 1 


\begin{tabular}{ccc}
\hline Nama Kelas & Data Training & Data Testing \\
\hline Aqua & 25 & 75 \\
\hline Coca-Cola & 25 & 75 \\
\hline Fanta & 25 & 75 \\
\hline Minute-Maid & 25 & 75 \\
\hline Sprite & 25 & 75 \\
\hline Jumlah & 125 & 375 \\
\hline
\end{tabular}

Pada pengujian pertama digunakan jumlah data citra Training sebanyak 125 dengan data citra Testing sebanyak 375 . Terlihat bahwa pada pengujian yang pertama ini jumlah data citra Training jauh lebih sedikit dari pada jumlah Testing. Perbedaan jumlah tersebut dimaksud untuk menguji model dengan data yang sebanyak mungkin, sehingga akan terlihat akurasi maksimal yang dapat dihasilkan.

Berdasarkan hasil pengujian terlihat bahwa sistem dapat mengklasifikasi dengan tepat diantaranya adalah prediksi untuk Kelas dengan merek Aqua yang berhasil memprediksi dengan sempurna. Selain itu kelas dengan merek MinuteMaid mendapatkan keberhasilan prediksi dengan cukup baik. Namun dari beberapa percobaan yang lainnya masih terdapat tingkat prediksi yang rendah. Jumlah total dari 375 data citra yang diujikan hanya 210 data citra yang berhasil diprediksi dengan benar. Percobaan pertama menghasilkan akurasi sebesar.

$\operatorname{Akurasi}(\%)=\frac{210}{375} \times 100 \%$

Akurasi $=56 \%$

Hasil perhitungan akurasi pada pengujian pertama menghasilkan nilai 56\%. Nilai tersebut masih kurang baik untuk teknik klasifikasi citra botol plastik.

\subsection{Hasil Pengujian Kombinasi data 2 (Model} 2)

Pengujian ke-2 dihasilkan dengan menggunakan 50\% data citra Training dan 50\% data citra Testing. Pada pengujian kedua pembagian data dibagi sama rata dari keseluruahn data citra yang digunakan. Pembagian pada percobaan ini terlihat pada Tabel 5 .

Tabel 5. Pembagian data kombinasi 2

\begin{tabular}{ccc}
\hline Nama Kelas & Data Training & Data Testing \\
\hline Aqua & 50 & 50 \\
\hline Coca-Cola & 50 & 50 \\
\hline Fanta & 50 & 50 \\
\hline Minute-Maid & 50 & 50 \\
\hline Sprite & 50 & 250 \\
\hline Jumlah & 250 &
\end{tabular}

Model 2 memiliki jumlah data Training yang lebih banyak dari pada yang sebelumya. Hasil pengujian ini memiliki jumlah prediksi benar lebih baik dari pada sebelumnya yaitu dari 250 data citra yang diujikan menghasilkan jumlah prediksi benar sebanyak 175 data citra. Beberapa merek botol plastik masih memiliki nilai akurasi yang masih sedikit. Namun terlihat bahwa nilai akurasi sudah mulai mengalami peningkatan.

$\operatorname{Akurasi}(\%)=\frac{175}{250} \times 100 \%$

Akurasi $=\mathbf{7 0} \%$

Berdasarkan hasil perhitungan akurasi sistem mendapatkan nilai sebesar 70\%. Nilai tersebut cukup bagus digunakan untuk klasifikasi citra botol plastik.

\subsection{Hasil Pengujian Kombinasi data 3 (Model 3)}

Pengujian terakhir dengan menggunakan data Training $75 \%$ dan data Testing 25\%. Kombinasi data tersebut terlihat seperti pada Tabel 6.

Tabel 6. Pembagian data data kombinasi 3

\begin{tabular}{ccc}
\hline \multirow{2}{*}{ Nama Kelas } & Data Training & Data Testing \\
\hline Aqua & 75 & 25 \\
\hline Coca-Cola & 75 & 25 \\
\hline Fanta & 75 & 25 \\
\hline Minute-Maid & 75 & 25 \\
\hline Sprite & 75 & 25 \\
\hline Jumlah & 375 & 125 \\
\hline
\end{tabular}

Data citra Training yang digunakan jauh lebih banyak dari pada pengujian yang sebelumnya yaitu dengan jumlah 375 data citra sehingga, data citra yang dilatih memiliki variasi yang lebih banyak. Hasil pengujian ketiga memiliki tingkat keberhasilan yang tinggi dari sebelumnya. Tingkat kesalahan pada pengujian ini cukup rendah. Sistem dapat memprediksi dengan benar sebanyak 105 dari 125 data yang diujikan. Berdasarkan hasil pengujian akurasi yang dihasilkan sebesar.

$$
\begin{aligned}
& \text { Akurasi( } \%)=\frac{42}{50} \times 100 \% \\
& \text { Akurasi }=84 \%
\end{aligned}
$$

Berdasarkan hasil pengujian yang sudah dilakukan pada hasil akurasi pengujian ketiga 
memiliki nilai akurasi yang tinggi yaitu 84\%. Nilai tersebut menjadi nilai akurasi paling tinggi pada penelitian ini saat sistem diujikan dengan data baru.

\subsection{Hasil Perbandingan Akurasi}

Berdasarkan hasil dari pengujian yang dilakukan perbandingan prosentase kombinasi data training dan data testing mendapatkan hasil seperti pada Tabel 7.

Tabel 7. Hasil Perbandingan Akurasi

\begin{tabular}{lllll}
\hline \multirow{2}{*}{ No } & \multirow{2}{*}{ Pengujian } & Jumlah Data & \multirow{2}{*}{$\begin{array}{l}\text { Akurasi } \\
\text { ny) }\end{array}$} \\
\cline { 3 - 4 } 1 & Praining & Testing & \\
\hline 2 & Pengujian 1 & 125 & 375 & 56 \\
\hline 3 & Pengujian 2 & 250 & 250 & 70 \\
\hline
\end{tabular}

Perbandingan akurasi dari 3 kali percobaan dengan 3 Model yang berbeda terlihat bahwa pengujian ke 3 yang menggunakan Model 3 menghasilkan akurasi sebesar 84\%. Berdasarkan hasil percobaan ini semakin banyak variasi data yang digunakan semakin baik tingkat akurasi.

Seluruh pengujian data yang dilakukan masih terdapat kesalahan pada saat memprediksi data yang diujikan. Kesalahan tersebut terjadi karena kurangnya data Training yang masih sedikit. Selain itu variasi data yang digunakan masih kurang beragam sehingga akan mengurangi tingkat prediksi pada saat proses pengujian. Faktor lain yang mungkin terjadi adalah bentuk dan warna dari data yang digunakan. Pada merek Coca-Cola dan Fanta bentuk dan warna hampir memiliki kemiripan. Keduanya memiliki warna yang sama yaitu merah. Karena data yang digunakan masih sedikit sistem masih kesulitan dalam mengelompokkan data. Berbeda dengan Aqua, Minute Maid dan Sprite yang memiliki bentuk dan warna yang berbeda sehingga dapat menghasilkan prediksi klasifikasi yang baik.

\section{KESIMPULAN}

Berdasarkan hasil penelitian yang sudah dilakukan dari 3 Model berdasarkan kombinasi antara jumlah data citra Training dan Testing dengan pembagian pada kombinasi 1 , kombinasi 2, dan kombinasi 3 menghasilkan akurasi berurutan sebesar 56\%, 70\%, dan 84\%. Klasifikasi menggunakan SVM dengan Multiclass One vs All yang telah dibuat sudah baik untuk melakukan klasifikasi botol plastik dengan menggunakan data Training yang lebih besar untuk meningkatkan hasil akurasi dan prediksi. Selain itu penggunaan data yang lebih beragam dan kualitas citra dapat dilakukan untuk mendapatkan hasil yang lebih baik.

\section{REFERENSI}

AUliA, S., HADIYOSO, S., \& RAMADAN, D. N. (2015). Analisis Perbandingan KNN dengan SVM untuk Klasifikasi Penyakit Diabetes Retinopati berdasarkan Citra Eksudat dan Mikroaneurisma. ELKOMIKA: Jurnal Teknik Energi Elektrik, Teknik Telekomunikasi, \& Teknik Elektronika, 3(1), 75. ttps://doi.org/10.26760/elkomika.v3i1.75

Banyal, N. A., Surianti, S., \& Dayat, A. R. (2016). Klasifikasi Citra Plasmodium Penyebab Penyakit Malaria dalam Sel Darah Merah Manusia dengan Menggunakan Metode Multi Class Support Vector Machine (SVM). ILKOM Jurnal Ilmiah, 8(2), 111-118. https://doi.org/10.33096/ilkom.v8i2.54.111 $-118$

Gitasari, R. A., Hidayat, B., \& Aulia, S. (2015). Klasifikasi Penyakit Diabetes Retinopati Berdasarkan Citra Digital Dengan Menggunakan Metode Wavelet Dan Support Vector Machine. Jurnal Teknik Elektro, 2(1), $1-5$.

Ibrahim, S., Zulkifli, N. A., Sabri, N., Shari, A. A., \& Noordin, M. R. M. (2019). Rice grain classification using multi-class support vector machine (SVM). IAES International Journal of Artificial Intelligence, 8(3), 215220.

https://doi.org/10.11591/ijai.v8.i3.pp215220

Neneng, N., Adi, K., \& Isnanto, R. (2016). Support Vector Machine Untuk Klasifikasi Citra Jenis Daging Berdasarkan Tekstur Menggunakan Ekstraksi Ciri Gray Level Co-Occurrence Matrices (GLCM). Jurnal Sistem Informasi Bisnis, 6(1), 1. https://doi.org/10.21456/vol6iss1pp1-10

P, I. W. S. E., Wijaya, A. Y., \& Soelaiman, R. (2016). Klasifikasi Citra Menggunakan Convolutional Neural Network ( Cnn ) pada Caltech 101. Jurnal Teknik ITS, 5(1), 65-69.

Riadi, I., Umar, R., \& Aini, F. D. (2019). Analisis Perbandingan Detection Traffic Anomaly Dengan Metode Naive Bayes Dan Support Vector Machine (Svm). ILKOM Jurnal Ilmiah, 11(1),

17-24. 
https://doi.org/10.33096/ilkom.v11i1.361.1 7-24

Thai, L. H., Hai, T. S., \& Thuy, N. T. (2012). Image Classification using Support Vector Machine and Artificial Neural Network. International Journal of Information Technology and Computer Science, 4(5), 32-38. https://doi.org/10.5815/ijitcs.2012.05.05

Umar, R., Riadi, I., \& Faroek, D. A. (2020). Komparasi Image Matching Menggunakan Metode K-Nearest Neighbor ( KNN ) dan Metode Support Vector Machine ( SVM ). Jurnal of Applied Informatics and Computing (JAIC), 4(2), 124-131.

Wang, Z., Peng, B., Huang, Y., \& Sun, G. (2019). Classification for plastic bottles recycling based on image recognition. Waste Management, 88, 170-181. https://doi.org/10.1016/j.wasman.2019.03. 032 